\title{
INFORMATION SUPPORT OF DESIGN INNOVATION ACTIVITY OF THE TECHNICAL UNIVERSITY
}

\author{
Lesya SHKITSA, Volodymyr KORNUTA, Olena KORNUTA, Iryna BEKISH, Vasyl BUI \\ Ivano-Frankivsk National Technical University of Oil and Gas
}

\begin{abstract}
:
The problem of adaptation of educational space of technical university to modern market requirements is considered. There are described the results of studying the requests of higher education applicants and their vision of the success of the study. The aim of the article is to build an architecture of an information system similar to that used by modern enterprises, which will provide a combination of scientific, design and educational activities of the academic community, taking into account market needs. The main scientific research methods are bibliographic analysis, comparative analysis, methods of analogies. The conceptual architecture of the Information Support of Design Innovation Activity of the Technical University system based on the construction of a unified scientific and educational information space is described. The main task of the university's information space is to prepare students for activities of the real market. There are determined the necessity and limits of application of the modern access control system at the universities of Ukraine, in particular for the organization of independent work of students. There is offered the way to reach the 4th level of technological readiness of students 'and teachers' development. The construction of an ontological description of the subject area of a technical university, the development of the application of a grid model for the description of scientific and technical information, and the determination of the current technical status are defined as the basis of the system of setting tasks for project groups in the transition to project-oriented learning. The question of the appropriateness of using adaptive case management system as a basic concept of building electronic document management system is resolved. The use of the competence approach as a mechanism of stimulating technical creativity within the educational process and in the work of researchers from the University staff is considered.
\end{abstract}

Key words: Educational activities, Educational information space, Technical University

\section{INTRODUCTION}

Developing innovative or customer-oriented products is an important prerequisite for success in the job market. Such developments are knowledge-intensive and require a sufficient number of engineering workers. On the other hand, product development time frames should be minimal, which dictates the need for experienced staff. And all these problems must be solved against the background of declining popularity of technical education [24]. We assume that the solution to these problems can be found taking into account the fact that the basis of modern methods of production organization is building an effective system of information support.

Known attempts to solve these problems are based on: 1) the use of practice-oriented training, up to the introduction of requirements for the launch of their own startup by potential graduates [2, 26];

2 ) introduction of the use of competence approach in education $[9,18]$.
In Ukraine, one of the ways for solving these problems is the introduction of dual education (proposed by the ministerial level [6]), as a form of education in which students spend part of their time in classrooms and the other part - in a real operating enterprise.

The capacity of the job market is limited even in large enterprises, at least in Ukraine. In addition, the global trend is to reduce the number of positions, which require higher education. This situation is a direct consequence of increased productivity because of the use of modern information technology [7, 30].

In the current conditions of the labour market and the rapid development of technologies, the role of the university, as a repeater of the knowledge accumulated in its literary repositories (and the academics' knowledge), loses its relevance $[19,22]$. The Internet offers a large variety of training programs. Each of them is more or less provided with multimedia educational materials.

The role of the university as an institution for certification of specialists loses its relevance as well [28]. Nowadays, 
firms are more likely to carry out their own corporate testing or to seek the services of specialized firms that test and certify according to certain methods and standards. It is not a $\mathrm{HEl}$ diploma that is more important to investors, but a business plan or outline for the start-up, selected on a competitive basis. All of these challenges call for new approaches to organizing university education for the training of engineers.

\section{LITERATURE REVIEW}

There are many systems in universities such as academic management system, examination system, online learning systems, student information system, faculty information system etc [12]. The common idea of all these systems is capturing the relevant data and representing and visualizing it in accordance with the requirements of users. This system is mainly intended to be used by the staff of student affair department and faculties of university. Currently this system is intended to be used by authenticated staff of student affair department for helping students with their academic activities.

The paper [4] discusses the need of a central repository to update and maintain a document management system so that stakeholders can access and make use of the information for their specific purposes. It is imperative that the university obtains and maintains accurate and relevant information about faculty's professional activities. This system helps to provide that ability and complements other information and management systems, all of which support university's institutional planning, core values and priorities.

The research of Saleh Alghamdi [1] proposes a low-priced attendance-checking system and that avoids consuming any time or effort from lecturers or students. This system can monitor the attendance of students without the limitations of other available systems.

The proposed Internet-of-Things Based Smart Resource Management System that could be used for commercial or educational purposes included an Arduino system used to scan a user ID and send the data to a cloud server to be retrieved for use in the Android application to check student attendance [11].

The system developed in [14] can analyze the data and display statistics about the student's absences, print reports about absence percentages and students' warnings for the specified period.

Scrum methodology in research groups at universities has been described in [20]. A. Jurado-Navas and R. MunozLuna think Scrum method can be considered as a good proposal to accomplish a high quality teaching-learning process at universities for three main reasons:

1) it improves the capacity of using the knowledge in a disciplined, critical and creative way;

2) it promotes the coexistence in heterogeneous human groups;

3) it develops the capacity of thinking, living and acting with complete autonomy [13].

The number of projects implemented in all sectors is increasing annually, and there is a tendency for them to become more complex and interdisciplinary [29].
The paper [8] builds upon a growing area of the critical analysis of project management practice, offering insights into the tension between the values and norms of university research and an on-going formalization of project management in some organizational contexts.

\section{DISCUSSION AND SCIENTIFIC RESEARCH RESULTS}

The majority of students consider higher education not only as a way of acquiring useful knowledge, but also as one of the mechanisms for improving social and work skills and developing skills to learn and build solutions based on information from different sources [5, 17, 21]. In this case, the sources should be formally reliable, that is, they must be either sources recommended by teachers or normative sources. The teacher, when making demands on the sources used, acts as a guarantor of their accuracy. An anonymous survey of first- and second-level IvanoFrankivsk National Technical University Oil and Gas (IFNTUOG) students (bachelors and masters) found that many of them (in different groups the percentage varies from $40 \%$ to $70 \%$ ) believe that it is enough to get acquainted with the subject in the first few lessons, and then all the needed information and often the solutions can be found on the Internet. Seemingly, this result is similar to allocating hours per discipline, proposed by the educational systems of the world and Ukraine, when the number of hours for extracurricular work exceeds. However, according to the results of the head-on check at the end of the semester, it turned out that independent carrying out of the work in such way is not ensured. Several online sources were repeated in most of the works, and students were not able to complete the task assignments that required manual work (e.g., pencil drawings or simple CAD system drawings).

Almost all senior students (over 90\%) declared that they were ready for intensive classroom and self-study, if the acquired knowledge and skills were necessary to take up job vacancies in the labour market or could give an advantage in the market in the short term (within one year). Such an advantage was described as the students' vision of success of learning. This program of work is typical for start-ups, although the readiness to create their own start-up declared no more than $3-5 \%$ of respondents to the survey.

Taking into consideration such a request of the market, the university should provide the following components: access to reliable information, mastering authentication skills by students, and organization of work in which students have the opportunity to improve their social and work skills.

On the basis of the comparative research of resource management, interaction and document flow systems the concept of the architecture of the system of information support of design innovation activity of the technical university is created, which schematic representation is shown in Fig. 1. 


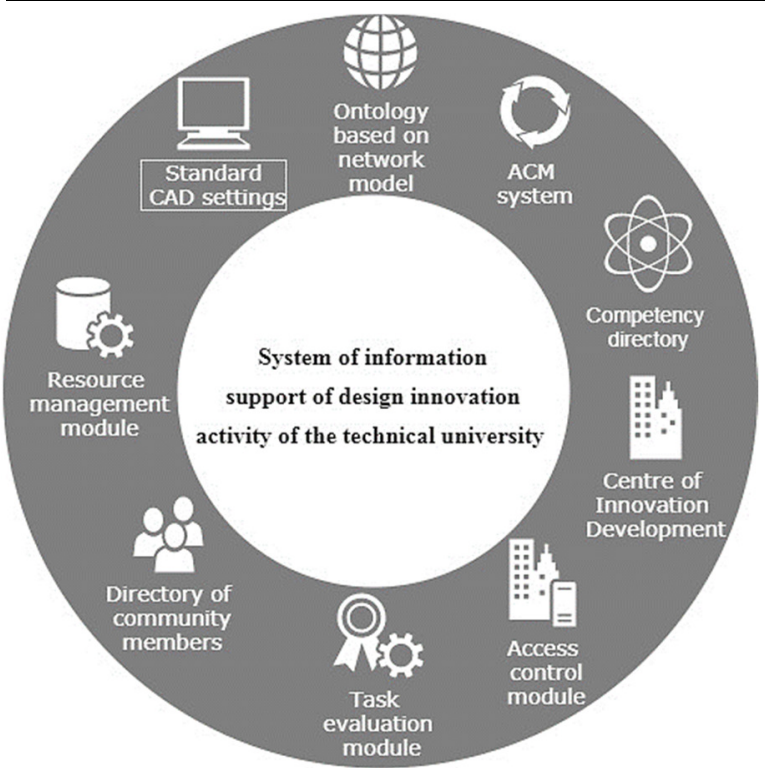

Fig. 1 Scheme of the architecture of the system of information support of design innovation activity of the technical university

A few scientific research methods (bibliographic analysis, comparative analysis, methods of analogies) were used during the concept creation process.

The experiment of using during lectures and the discipline one of the BYOD approaches $[10,16]$ showed that practically all students now have mobile computing devices (smartphones, tablets, laptops) with the possibility of wireless connection to corporate and/or global network. It should be noted that the students were given the opportunity to make individual choices with or without a mobile device. Everyone (100\%) chose to work with mobile devices.

Thus, it is possible to implement the system of students' registration in the university's information system and the automatic tracking of their presence in classes and in rooms reserved for independent work. The registration system can be implemented both in networks with support of wi-fi, and in networks without such a support. IFNTUOG has implemented a single corporate network and the work to prepare a regulatory framework and introduce a set of network administration rules that will allow the automatic registration of students' presence in classrooms during classes is being done. In addition to controlling students' attendance in classes, this system will also allow to track time and analyse students' self-study habits.

It should be noted at the outset that such control does not restrict the freedom of students, but only brings them closer to the current conditions of the labour market. Employers are now introducing various methods of controlling their employees: from access control to time-tracking, from automation of door-to-door controls or using of CCTV cameras with motion recognition and face identification, to implantation of chips [3]. Moreover, teacher attendance control is ineffective, given the tendency to consolidate classes (enlarging number of students in one class) [25].

An extensive study by Wagner and Dintersmith [28] shows that organizing student leisure is one of the factors behind the rise of the cost of education in the US, while the cost of extracurricular work is decreasing. In Ukraine, the scale of the costs of organizing leisure is smaller, but student extracurricular work is organized, in most cases, in the form of tasks that students can complete at home or in the library, online or using books. It is noted above that in modern conditions this type of teaching is not very effective.

It is obvious that the control of location alone does not allow the calculation and theoretical tasks to be performed independently. But such control will allow to organize independent work that requires specialized equipment (the system should also provide photo/video fixation). Students who have the appropriate admission from the teacher or master (based on proven knowledge and skills to use the equipment safely) will be able to come to the laboratory/workshop on their own and complete the assigned tasks.

To avoid overlays, wait and downtime, the information system should include a resource management module (scheduling of equipment/resource use) or an electronic queue [15]. A register of equipment and resources is also required, which should be accessible to all interested people with valid access to the work (use of equipment and resources). IFNTUOG is working on the preparation and commissioning of a pilot project for such a system module based on the laboratories of the Department of Engineering and Computer Graphics [23].

The laboratory, prepared for independent work of students, is one of the components of overcoming the abovementioned paradoxes and problems of technical higher education. The implementation of the laboratory at IFNTUOG is foreseen in the framework of the Ro-Ua Transborder Academic Development for Research and Innovation 2 SOFT/1.2/86 project. Such a laboratory will enable researchers and university students to create innovative products on their own (at least up to the prototype level, TRL from 4 to 6 according to [27]). The expected result of the laboratory's work is to create a unified environment of innovation for the participants of the academic community, as well as to test the model of project-oriented technical education. Such a model can be constructed in two variants:

1) undergraduate students work with solutions known in the technical literature (e.g., on the basis of patents), implementing them according to the patent or creating their models from more accessible/technological materials;

2) senior students (or younger ones, if they wish) start their own start-ups and bring them to the "seed" stage. However, both options must function in a unified innovation environment of the university.

The unified environment of the university's innovation activity will consist of two components, the activity of either of which separately will not allow to overcome the abovementioned paradoxes and problems of technical higher education. The first component will be the Laboratory for students' independent work, the second - the subsystem of the information system of the university, as the basis of information support for design innovation activity.

Such subsystem should consist of the abovementioned modules of self-study of students, as well as modules that 
will provide access to the necessary knowledge and modules that will link innovative and educational work.

Practice-oriented learning requires a large number of task options. Tasks can be obtained from several sources: projects for the implementation of experimental research on patent applications and scientific and technical literature (e.g., to confirm their validity); requests for the fulfilment of certain production or scientific-production tasks from real-life enterprises; queries for start-ups (subject to confidentiality); current scientific developments of the participants of the academic community. In order to register such requests in the information system, there must be a knowledge base with access tools. This knowledge base is also based on the network model. The current standards of Ukraine for the development and beginning of manufacturing of products provides a similar grid model in the form of a system of coding (assigning codes) of documentation.

In the process of developing a system of information support for innovative work involving the innovative potential of students and incorporating innovative work into the academic load of teachers, the standardization model of the equipment based on ISO 15926 was adopted by the main model of ensuring the interconnection of equipment on the basis of ISO 15926 schemes. The department of Engineering and Computer Graphics performs work on the creation of university ontology and RDF schemes as it is the basic department for teaching students of different specialties the ways and methods of describing technical ideas in different fields of knowledge. At this point, the geometric kernel of the description is created.

In addition to compiling descriptions, the task was to ensure that the document storage and formatting system is resistant to changes in CAD formats and versions. PLM systems on the market are focused on software and related file formats from specific vendors. Therefore, it was decided to use a non-specialized electronic document management system in adaptive case management (ACM) form. Modern versions of all CAD applications used in IFNTUOG have the ability to set construction design office standards. Therefore, recommendations for setting these standards have been developed. To provide CAD-independent opening of drawings and other design documentation, the step of creating "electronic blues" in the form of *.pdf/A documents and control cards in text format (JSON, XML and related schematics) has been added to the documentation exchange and deposition processes.

As the task of involving students to perform design work in the course of the University's innovation activities was set, the use of classical systems of product development management and project execution was found to be ineffective due to the need to ensure the stability of the system with respect to frequent change of contractors. Flexible management systems (such as Kanban, ACM), together with scheduling systems, have proven to be very good when tested in mixed design teams. The ability to view the list of restrictions and open tasks (for which no one is responsible yet) allows planning the work and independently determining the ability to perform the role of the project task doer. In addition, such systems have integrated means of controlling timeliness of execution. The task is considered closed if the person who has the right to confirm its performance has done so or the contractor has downloaded the necessary documents and within a certain time has not received their negative evaluation. The systems are configured so that the author of the assignment, other profile teachers or the project manager can act as controllers. In this way, both teachers and students are involved in the work (teachers as authors, controllers and/or performers, students as authors and/or performers).

Performing tasks that involve the creation of new design solutions, as a rule, requires a combination of several works: geometric design/modelling, correct use or construction of new calculation models, experimental verification of compliance with the tasks. In doing so, the contractor must have the competencies that are traditionally provided by the disciplines of different years of study or of different training programs. There are several ways of solving the following problem:

1) forming project teams with participants from different years of study/specialty (the task is divided into sub-tasks with imposing restrictions);

2) on the basis of a composite ontology, the author of the task searches for suitable practices and compiles a list of competencies that characterize each of the practices.

The first way involves the subdivision of the task into subtasks by the author, defining the competencies needed to solve each sub-task. A student may choose to complete only those sub-tasks that require competencies that they still need to acquire. Each participant's already acquired and available competencies are taken from the Learning Management System (LMS).

The second way is based on a set of competencies that characterize each practice described in the ontology. The student can choose only those tasks that require such a set of competencies that he has not yet acquired, which can be mastered within the project deadline. Otherwise, they must choose from the available subtasks (the first way).

If the student is the author of such a task, they may adjust the term of the task. This will allow each student to consciously choose their trajectory of study (assessing the tasks that they are focused on and the estimated time of acquisition of the competencies required for them).

If the task cannot be described using complex ontologies, the task is to extend the ontology. Masters or academics can take on such tasks. If the author of such a task is a student of the first level of study, they can divide such a task into the described subtasks (and, accordingly, use the second way of solving) or try to involve in the project team of one of the masters or academics.

Thus, the described solution is based on a competence approach.

\section{CONCLUSIONS}

The described variant of construction of the Information Support of Design Innovation Activity of the Technical University system is intended to intensify the involvement of 
students, as participants of the academic community, in setting and solving problems of innovative development. The introduction of flexible project management approaches and the improvement of the system of describing the achievements and tasks of the university are aimed at enhancing the involvement of business in updating educational tasks. The unification of scientific, design and educational activities of the university into a single information space requires the construction of an information system similar but not identical to that used in industry. The use of modern control technologies in such information system helps to adapt students to the requirements of the labour market and to improve the self-organization of the student's work time.

The effectiveness of implementation of the proposed information support system in accordance with the current legislation of Ukraine, the interest of market participants (entrepreneurs, students, teachers) and their assessment of the system activity, the experience of implementation of real projects in the conditions of the system of information support of design innovation activity of the technical university will be the main areas of further research.

\section{ACKNOWLEGEMENT}

The work is carried out on the basis of the task of the Ministry of Education and Science of Ukraine to Ivano-Frankivsk National Technical University of Oil and Gas (the topic \#0118u006752 "Improvement of methods of innovation design activity in the oil and gas industry". This article was created under the support of Joint Operational Programme, funded by ENI CBC Ua-Ro 2014-2020 2SOFT/1.2/86. Project title: Ro-Ua Trans-border Academic Development for Research and Innovation.

\section{REFERENCES}

[1] S. Alghamdi. "Monitoring Student Attendance Using A Smart System at Taif University." International Journal of Computer Science \& Information Technology (IJCSIT), vol 11, No 1, pp.107-115, Feb. 2019. http://dx.doi.org/10.2139/ssrn.3439186

[2] T.B. Astebro, N.Bazzazian and S.Braguinsky. (2011, Jul.) "Startups by Recent University Graduates and their Faculty - Implications for University Entrepreneurship Policy." SSRN. [On-line]. pp. 50. Available: http://dx.doi.org/10.2139/ssrn.1752832 [Feb. 15, 2020].

[3] M. Astor. "Microchip Implants for Employees? One Says Yes." The New York Times (Jul. 25, 2017). Internet: https://www.nytimes.com/2017/07/25/technology/microchips-wisconsin-company-employees.html [Feb. 15, 2020].

[4] R.Bhatnagar, A. Kumar \& S. Gupta. "Role of Information Systems in an University Setup - A Case Study." International Journal of Computer Science and Electronics Engineering (IJCSEE), vol. 4, pp. 151-156, Dec. Availabl: https://www.researchgate.net/publication/317649791_Role_of_Information_Systems_in_an_University_Setup_-_A_Case_Study

[5] T. Chamorro-Premuzic, A. Arteche, A. Bremner, C. Greven, \& A. Furnham. "Soft skills in higher education: Importance and improvement ratings as a function of individual differences and academic performance." Educational Psychology, vol. 30, pp. 221-241, Feb. 2010. https://doi.org/10.1080/01443410903560278
[6] "Dual education." Internet: https://mon.gov.ua/ua /osvita/profesijno-tehnichna-osvita/dualna-osvita [Feb.15, 2020].

[7] M. Ford. Rise Of The Robots: Technology and the Threat of a Jobless Future. Basic Books. New York, 2015, pp. 200.

[8] N. Fowler, M. Lindahl, D. Sköld. (2015). "The Projectification of University Research - A study of resistance and accommodation of project management tools and techniques." International Journal of Managing Projects in Business, vol. 8, pp. 9-32, Jan. 2015. https://www.researchgate.net/publication/266259424_The_Projectification_of_University_Research_-_A_study_of_resistance_and_accommodation_of_project_management_tools_and_techniques

[9] J. Glaesser. "Competence in educational theory and practice: a critical discussion". Journal Oxford Review of Education, vol. 45 (1), pp. 70-85, Aug. 2018. https://doi.org/10.1080/03054985.2018.1493987

[10] A. Halimaton, A. Zul, I. Shaharudin \& Z. Mohd. "Byod Implementation in University: Balancing Accessibility and Security," in Proc. $2^{\text {nd }}$ International Conference on Education, Business, Islamic and Technology (ICEBIT 2018), 2018, pp. 145-154. Internet: https://www.researchgate.net/publication/329309815_BYOD_IMPLEMENTATION_IN_UNIVERSITY_BALANCING_ACCESSIBILITY_AND_SECURITY [Feb. 15, 2020].

[11] J He, A Atabekov, H M Haddad. "Internet-of-Things Based Smart Resource Management System: A Case Study Intelligent Chair System," in Proc. 25 th International Conference on Computer Communication and Networks (ICCCN), 2016, $\mathrm{pp}$. 1-6 https://doi.org/10.1109/ICCCN.2016.7568533

[12] T. Htwe \& M. Aung. "Development of Information System for a University." International Journal of Scientific and Research Publications, vol. 9(6), pp. 494-499, Jun. 2019. http://dx.doi.org/10.29322/IJSRP.9.06.2019.p9071.

[13] A. Jurado-Navas \& R. Munoz-Luna. "Scrum Methodology in Higher Education: Innovation in Teaching, Learning and Assessment." International Journal of Higher Education. vol. 6, pp. 1-18, Nov. 2017. doi:10.5430/ijhe.v6n6p1

[14] J. Karwan, I. Falah \& Z. Shahab. "Student Attendance Management System." International Journal of Engineering and Technology, vol. 6, pp. 49-53, Feb. 2018. DOI: 10.21276/sjet.2018.6.2.1

[15] V. Kornuta. (2015, Jan.). "Free Laboratory at the Technical University." Information Technology and Learning Tools. [On-line]. 45(1), pp. 106-122. Available: http://journal.iitta.gov.ua/index.php/itlt/article/view/1178/890 [Feb. 15, 2020].

[16] V. Kornuta and O. Kornuta. "Experience in Teaching Engeneering Disciplines in the Light of Today's Challenges," in Proc. Progressive Technologies in Engineering PTME-2019, 2019, pp. 48-50.

[17] S.Mendo-Lázaro, B.León-Del-Barco, E. Felipe-Castaño, M. Polo-Del-Río, D.Iglesias-Gallego. (2018, Aug.). “Cooperative Team Learning and the Development of Social Skills in Higher Education: The Variables Involved." Front Psychol. [On-line]. vol. 9 (1536). Availabl: https://dx.doi.org/10.3389\%2Ffpsyg.2018.01536 [Feb. 15, 2020].

[18] N. O'Sullivan and A.Bruce. "Teaching and Learning in Competency Based Education," in Proc. The Fifth International Conference on e-Learning (eLearning-2014), 2014. Internet: https://www.researchgate.net/publication/269810124_Teaching_and_Learning_in_Competency_Based_Education [Feb. 15, 2020]. 
[19] N. Pasyeka and M. Pasyeka. "Construction of multidimensional data warehouse for processing students' knowledge evaluation in universities," in Proc. The $13^{\text {th }}$ International Conference on Modern Problems of Radio Engineering, Telecommunications and Computer Science (TCSET), 2016, pp. 822-824. https://doi.org/10.1109/TCSET.2016.7452195

[20] D. B. Ramos, I. M. Ramos, W. S. Viana, G. Silva, E. de Oliveira "On the use of Scrum for the management of researchoriented projects." Nuevas Ideas en Informática Educativa, Vol. 12, pp. 589-594, Dec.2016. http://www.tise.cl/volumen12/TISE2016/589-594.pdf

[21] Y. Romanyshyn, V. Sheketa, V. Pikh, L. Poteriailo, Y. Kalambet and N. Pasieka. "Social-Communication Web Technologies in the Higher Education as Means of Knowledge Transfer," in Proc. 14 ${ }^{\text {th }}$ International Conference on Computer Sciences and Information Technologies (CSIT), 2019, pp. 35-38. https://doi.org/10.1109/STCCSIT.2019.8929753

[22] L. Shkitsa, V. Kornuta, O. Kornuta, I. Bekish. The model of informational space for innovation and desing activities in the university. Science and Innovation, Vol. 15(6). pp. 1422, Dec. 2019.2 DOI: https://doi.org/10.15407/scin15.06.014.

[23] L. Shkitsa, V. Kornuta, O. Kornuta. "Single information space for innovation activity of industry-specific higher education institution". Scientific Bulletin of Ivano-Frankivsk National Technical University of Oil and Gas, vol.2(47), pp. 57-64, Dec. 2019. DOI: 10.31471/1993-9965-2019-2(47)57-64.

\section{Lesya Shkitsa}

ORCID ID: 0000-0002-5352-3978

Ivano-Frankivsk National Technical University

of Oil and Gas,

Institute of Engineering Mechanics,

Department of Engineering and Computer Graphics, 15, Karpatska Str., 76019, Ivano-Frankivsk, Ukraine e-mail: Ishkitsa@nung.edu.ua

\section{Volodymyr Kornuta}

ORCID ID: 0000-0002-3345-2578

Ivano-Frankivsk National Technical University

of Oil and Gas,

Institute of Engineering Mechanics,

Department of Engineering and Computer Graphics, 15, Karpatska Str., 76019, Ivano-Frankivsk, Ukraine e-mail: v.kornuta@nung.edu.ua

\section{Olena Kornuta}

ORCID ID: 0000-0002-0626-888X

Ivano-Frankivsk National Technical University

of Oil and Gas,

Institute of Engineering Mechanics,

Department of Engineering and Computer Graphics, 15, Karpatska Str., 76019, Ivano-Frankivsk, Ukraine e-mail: o.kornuta@nung.edu.ua
[24] L. Shkitsa, V. Panchuk, V. Kornuta. "Innovative methods of popularizing technical education", IOP Conference Series: Materials Science and Engineering, vol. 200, Issue 1, May 2017. DOI:10.1088/1757-899X/200/1/012023

[25] Ch.A. Stanley and M. E. Porter. Engaging Large Classes: Strategies and Techniques for College Faculty. Boston: Anker Publishing Company, Inc., 2002, 384 p.

[26] N. Stijn, F.J. Rijnsoever and M. Veelen. "Exploring the motives and practices of university - startup interaction: evidence from Route 128." The Journal of Technology Transfer, vol. 43, pp. 674-713, Jun. 2018 https://doi.org/10.1007/s10961-017-9625-5

[27] "The TRL Scale as a Research \& Innovation Policy Tool, EARTO Recommendations." Internet: https://www.earto.eu/wp-content/uploads/The_TRL_Scale_as_a_R_I_Policy_Tool__EARTO_Recommendations_-_Final.pdf , Apr. 30, 2014 [Feb. 15, 2020].

[28] T. Wagner, T. Dintersmith. Most Likely to Succeed: Preparing Our Kids for the Innovation Era. Scribner, 2016, pp. 304. ISBN 9781501104329.

[29] Z. Waheed. "Understanding Project Management: Skills and Insights for Successful Project Delivery." Facilities, Vol. 34, pp. 493-494, May 2016. https://doi.org/10.1108/F-092015-0068

[30] R. Wright. "Workplace automation: how Al is coming for your job." Financial Times (Sep. 29, 2019). Internet: https://www.ft.com/content/c4bf787a-d4a0-11e9-a0bdab8ec6435630 [Feb. 15, 2020].

\section{Iryna Bekish}

ORCID ID: 0000-0003-1910-9009

Ivano-Frankivsk National Technical University

of Oil and Gas,

Institute of Engineering Mechanics,

Department of Engineering and Computer Graphics, 15, Karpatska Str., 76019, Ivano-Frankivsk, Ukraine e-mail: i.bekish@nung.edu.ua

\section{Vasyl Bui}

ORCID ID: 0000-0003-3258-2167

Ivano-Frankivsk National Technical University

of Oil and Gas,

Institute of Engineering Mechanics,

Department of Engineering and Computer Graphics, 15, Karpatska Str., 76019, Ivano-Frankivsk, Ukraine e-mail: vasylbui@gmail.com 